\title{
Correction to: Dynamic behavior of prostate cancer cells under antitumor immunity and pulse vaccination in a random environment
}

\author{
Huan Yang • Yuanshun Tan
}

Published online: 2 August 2021

(C) Springer Nature B.V. 2021

\section{Correction to: Nonlinear Dyn \\ https://doi.org/10.1007/s11071-021-06614-w}

The article has been updated. The original article has been corrected.

Publisher's Note Springer Nature remains neutral with regard to jurisdictional claims in published maps and institutional affiliations.

The online version of the original article can be found under https://doi.org/10.1007/s11071-021-06614-w.

H. Yang · Y. Tan $(\varangle)$

College of Mathematics and Statistics, Chongqing Jiaotong

University, Chongqing 400074, China

e-mail: tanys625@163.com 